\title{
Is God really good to the upright? Theological educators exploring Psalm 73 through the Jungian lenses of sensing, intuition, feeling and thinking
}

\begin{tabular}{|c|c|}
\hline \multicolumn{2}{|c|}{$\begin{array}{l}\text { Authors: } \\
\text { Leslie J. Francis }{ }^{1,2} \\
\text { Susan H. Jones } \\
\text { Christopher F. Ross }\end{array}$} \\
\hline \multicolumn{2}{|c|}{$\begin{array}{l}\text { Affiliations: } \\
{ }^{1} \text { Warwick Religions and } \\
\text { Education Research Unit, } \\
\text { University of Warwick, } \\
\text { Warwick, United Kingdom }\end{array}$} \\
\hline \multicolumn{2}{|c|}{$\begin{array}{l}{ }^{2} \text { Department of New } \\
\text { Testament and Related } \\
\text { Literature, Faculty of } \\
\text { Theology and Religion, } \\
\text { University of Pretoria, } \\
\text { Pretoria, South Africa }\end{array}$} \\
\hline \multicolumn{2}{|c|}{$\begin{array}{l}{ }^{3} \text { Liverpool Cathedral, } \\
\text { Liverpool, United Kingdom }\end{array}$} \\
\hline \multicolumn{2}{|c|}{$\begin{array}{l}{ }^{4} \text { Martin Luther University, } \\
\text { Waterloo, Canada }\end{array}$} \\
\hline \multicolumn{2}{|c|}{$\begin{array}{l}\text { Research Project Registration: } \\
\text { Project Leader: A.G. van Aarde } \\
\text { Project Number: } 2334682\end{array}$} \\
\hline \multicolumn{2}{|c|}{$\begin{array}{l}\text { Description: } \\
\text { This research is part of the } \\
\text { research project, 'Biblical } \\
\text { Theology and Hermeneutics', } \\
\text { directed by Prof. Dr Andries } \\
\text { van Aarde, Post Retirement } \\
\text { Professor and Senior Research } \\
\text { Fellow in the Dean's Office, } \\
\text { Faculty of Theology and } \\
\text { Religion, University of Pretoria. }\end{array}$} \\
\hline \multicolumn{2}{|c|}{$\begin{array}{l}\text { Corresponding author: } \\
\text { Leslie Francis, } \\
\text { leslie.francis@warwick.ac.uk }\end{array}$} \\
\hline \multicolumn{2}{|c|}{$\begin{array}{l}\text { Dates: } \\
\text { Received: } 29 \text { May } 2020 \\
\text { Accepted: } 05 \text { Aug. } 2020 \\
\text { Published: } 08 \text { Dec. } 2020\end{array}$} \\
\hline \multicolumn{2}{|l|}{ Read online: } \\
\hline 回保回 & $\begin{array}{l}\text { Scan this QR } \\
\text { code with your } \\
\text { smart phone or } \\
\text { mobile device } \\
\text { to read online. }\end{array}$ \\
\hline
\end{tabular}

Psalm 73 is a challenging Psalm in which the Psalmist draws on rich imagery to juxtapose doctrine and experience and to juxtapose the goodness of God with divine retribution. Drawing on data provided by 15 theological educators within the Anglican Diocese of Cyprus and the Gulf, this study tests the thesis that the imagery of Psalm 73 will be perceived differently by sensing types and by intuitive types and that the issue 'Is God really good to the upright?' will be judged differently by feeling types and by thinking types. The findings from this study are consistent with the broader hermeneutical theory that the psychological type profile of the reader, in terms of perceiving preference and judging preference, plays a formative part in shaping the interpretation of biblical material.

Contribution: Situated within the reader-perspective approach to biblical hermeneutics, the SIFT method is concerned with identifying the influence of the psychological type of the reader in shaping the interpretation of text. The present study demonstrates that this theory holds true for the way in which theological educators read Psalm 73.

Keywords: biblical hermeneutics; reader perspective; psychological type; SIFT; empirical theology.

\section{Introduction}

The Psalms comprise a core component of the biblical tradition and a core resource within Christianity worship. Some of the Psalms are nonetheless challenging and problematic in terms of the messages they convey and the images of God they imply. Psalm 73 is amongst the challenging and problematic Psalms. At face value, the Psalmist is facing a crisis of confidence in inherited religious doctrine. The doctrine proclaims that God is good to the upright, but the Psalmist's experience shows that the wicked prosper better than the upright. The Psalmist resolves this paradox in terms of revelation received in the sanctuary of God, revelation that affirms the final destruction of the wicked. Commenting on Psalm 73, Kirkpatrick (1903:431) pointed to 'the double problem of the prosperity of the wicked and the suffering of the righteous'. Weiser (1962) argued that Psalm 73 'is a powerful testimony to a battle fought in a human soul comparable with that in the Book of Job' (p. 507). The problem debated in ancient Israel is no less a problem within the Christian community today.

The diverse ways in which theological educators may read and respond to the challenges posed by Psalm 73 offer an interesting context in which to test the hermeneutical theory proposed by the sensing, intuition, feeling and thinking (SIFT) approach to biblical interpretation and liturgical preaching (see Francis \& Village 2008). The SIFT approach belongs to the reader perspective tradition of biblical interpretation and draws on psychological type theory to characterise the location of the reader. Psychological type theory, as originally conceptualised by Jung (1971) and subsequently developed and operationalised by instruments such as the Myers-Briggs Type Indicator (Myers \& McCaulley 1985), the Keirsey Temperament Sorter (Keirsey \& Bates 1978) and the Francis Psychological Type Scales (Francis 2005) draws attention to the distinctive voices of the two perceiving functions (sensing and intuition) and to the distinctive voices of the two judging functions (feeling and thinking). The SIFT approach to biblical hermeneutics maintains that individuals who prefer sensing (sensing types) and individuals who prefer intuition (intuitive

How to cite this article: Francis, L.J., Jones, S.H. \& Ross, C.F., 2020, 'Is God really good to the upright? Theological educators exploring Psalm 73 through the Jungian lenses of sensing, intuition, feeling and thinking', HTS Teologiese Studies/Theological Studies 76(1), a6171. https://doi. org/10.4102/hts.v76i1.6171

Copyright: @ 2020. The Authors. Licensee: AOSIS. This work is licensed under the Creative Commons Attribution License. 
types) perceive biblical texts in different ways and that individuals who prefer feeling (feeling types) and individuals who prefer thinking (thinking types) evaluate biblical texts in different ways.

The perceiving functions are concerned with the way in which people receive and process information; this can be done through use of sensing or through use of intuition. Sensing types (S) tend to focus on specific details, rather than the overall picture. They are concerned with the actual, the real and the practical and tend to be down-to-earth and matter-offact. They may feel that particular details are more significant than general patterns. They are frequently fond of the traditional and conventional. In contrast, intuitive types (N) focus on the possibilities of a situation, perceiving meanings and relationships. They may feel that perception by the senses is not as valuable as information gained from the unconscious mind; indirect associations and concepts impact their perceptions. They focus on the overall picture, rather than specific facts and data. According to this theory, it would be hypothesised that sensing types and intuitive types would perceive the poetic imagery in Psalm 73 in different ways.

The judging functions are concerned with the way in which people make decisions and judgements; this can be done through use of objective, impersonal logic or subjective interpersonal values. Thinking types $(\mathrm{T})$ make judgements based on objective, impersonal logic. They value integrity and justice. They are known for their truthfulness and for their desire for fairness. They consider conforming to principles to be of more importance than cultivating harmony. They are often good at making difficult decisions as they are able to analyse problems in order to reach an unbiased and reasonable solution. In contrast, feeling types (F) make judgements based on subjective, personal values. They value compassion and mercy. They are known for their tactfulness and for their desire for peace. They are more concerned to promote harmony than to adhere to abstract principles. They are able to take into account other people's feelings and values in decision-making and problem-solving, trying to reach a solution that satisfies everyone. According to this theory, it would be hypothesised that feeling types and thinking types would evaluate the image of God portrayed in Psalm 73 in different ways.

The theory underpinning the SIFT approach to biblical hermeneutics has been explored in a sequence of qualitative studies in which 'readers' have been invited to work in groups that share the same psychological type preferences to explore specific passages of scripture. The theory is that such groups (constituted on the basis of psychological type preference) lead to greater clarity and greater distinctiveness of the type-associated readings of text. The initial studies to work in this way focused on the Gospels and included the following passages: the feeding of the 5000 reported in Mark 6:34-44 (Francis 2010); the resurrection narratives reported in Mark 16:1-8 and Matthew 28:1-15 (Francis \& Jones 2011); the cleansing of the Temple and the incident of the fig tree reported in Mark 11:11-21 (Francis 2012a; Francis \& ap Siôn 2016b); the Johannine feeding narrative reported in John 6:4-22 (Francis 2012b); the narrative of separating sheep from goats reported in Matthew 25:31-46 (Francis \& Smith 2012); the birth narratives reported in Matthew 2:13-20 and Luke 2:8-16 (Francis \& Smith 2013); two narratives concerning John the Baptist reported in Mark 1:2-8 and Luke 3:2b-20 (Francis 2013; Francis \& Smith 2014); the Johannine feeding narrative reported in John 6:5-15 (Francis \& Jones 2014); two passages from Mark exploring different aspects of discipleship reported in Mark 6:7-14 and Mark 6:33-41 (Francis \& Jones 2015a); the foot washing account reported in John 13:2b-15 (Francis 2015); two healing narratives reported in Mark 2:1-12 and Mark 10:46-52 (Francis \& Jones 2015b); the narrative of blind Bartimaeus reported in Mark 10:46-52 (Smith \& Francis 2016); the Road to Emmaus narrative reported in Luke 24:13-35 (Francis \& ap Siôn 2016a; Francis \& Smith 2017); the Lucan call of the first disciples reported in Luke 5:1-7 (Francis \& ap Siôn 2017); the missionary journey reported in Mark 6:6b-16 (Francis, Smith \& Francis-Dehqani 2017); the Matthean pericopes on Pilate and Judas in Matthew 27:3-10, 19-25 (Francis \& Ross 2018); the account of the Baptism of Jesus in Mark 1:4-9 (Francis, Jones \& Martinson 2019); the search for the lost sheep in Matthew 18:10-14 (Jones \& Francis 2019); the Beatitudes in Matthew 5:1-12 (Francis, Strathie \& Ross 2019); and the teaching about binding and loosing on earth in Matthew 18:15-18 (Francis, Jones \& Hebden 2019). More recently this research tradition has also been applied to the Psalms: Psalm 1 (Francis, McKenna \& Sahin 2018; Francis \& Smith 2018) and Psalm 139 by Francis, Smith and Corio (2018). The present study has been designed to build on this introduction of the SIFT approach to the Psalms by focusing now on Psalm 73 .

\section{Research question}

Building on the empirical research tradition concerned with exploring the SIFT approach to biblical hermeneutics and liturgical preaching, the aim of the present study was to invite an international group of theological educators serving within an Anglican context in Cyprus to work in type-alike groups to explore their reading of two sections drawn from Psalm 73. The first set of three type-alike groups was structured on the basis of the perceiving process (distinguishing amongst clearly defined sensing types, clearly defined intuitive types and individuals with less strong preferences on the perceiving process) to explore verses 1-10 that are rich in material to engage the perceiving process. The second set of three type-alike groups was structured on the basis of the judging process (distinguishing amongst clearly defined feeling types, clearly defined thinking types and individuals with less strong preferences on the judging process) to explore verses 15-20 and 27-28 that are rich in material to engage the judging process. By creating three groups in this way and by analysing and comparing the responses of the two contrasting clearly defined groups, the thesis is being tested that type characteristics are reinforced in such groups, where discussion proceeds without disturbance from the contrasting group. 


\section{Method}

\section{Procedure}

The context was a 3-day programme of continuing professional development for theological educators working within the Anglican Diocese of Cyprus and the Gulf. The scene was set for the workshops by exploring the theology of individual differences, by offering an introduction to psychological type theory and by inviting participants to complete a copy of the Francis Psychological Type Scales (Francis 2005). For the first set of workshops, the 15 participants divided into three groups of five clearly defined sensing types, four clearly defined intuitive types and six individuals with less strong preferences on the perceiving process. For the second set of workshops, the 15 participants divided into three groups of six clearly defined feeling types, four clearly defined thinking types and five individuals with less strong preferences on the judging process. All groups were asked to appoint one participant to take notes of the discussion and to report back to the plenary session so that the insights of each group could be shared with those in other groups.

\section{Materials}

The participants in the groups arranged according to the perceiving process were given a printed copy of Psalm 73:1-10 from the New Revised Standard Version (Anglicised Edition), a passage rich in material to engage the perceiving process, with the following instructions: What do you see in this description? (sensing); What ideas does the passage set running in your mind? (intuition). The participants in the groups arranged according to the judging process were given a printed copy of Psalm 73:15-20, 27-28 from the New Revised Standard Version (Anglicised Edition), a passage rich in material to engage the judging process, with the following instructions: What issues in this passage touch your heart? (feeling); What issues in this passage stretch your mind? (thinking).

\section{Analysis}

One of the authors served as an observer in each of the clearly defined type groups and noted the discussion carefully. The following analysis documents the discussion.

\section{Results: Psalm 73:1-10}

\section{Sensing types}

The group of five clearly defined sensing types began by arguing about the process and wanting to be clear that they had fully understood the task correctly. They eventually settled on the process of reading the piece of scripture silently. The silence was broken by one participant asking how they were going to discuss the piece of scripture, in a further attempt to clarify the process. Another participant responded by asking if anyone wanted to make a comment. The group was really taking a long time to get started.
When eventually the group launched into the discussion, one participant began by stating that the Psalmist was talking about the goodness of God and the movement from God's goodness to the injustices in the world. The idea of goodness was then picked up by other members of the group. One participant felt that Psalm 73 was like a child having a tantrum: the Psalmist seems to be saying 'I am good, but everyone else is evil'. Another participant talked about the Psalmist being good whilst everyone else is bad.

This line of thought led the group to think about envy, the envy experienced and given voice by the Psalmist, 'For I was envious of the arrogant'. One member of the group spoke about how the arrogant were allowed to get away with being arrogant, and about how indeed the arrogant appeared to be rewarded for their arrogance when everyone praised them. Another participant pointed to the sense of unfairness in all that. For this person, the Psalmist's envy came because the arrogant had been allowed to get away with their arrogance.

As the group of clearly defined sensing types moved step-bystep through the verses of Psalm 73, they spoke at length on the last verse:

Therefore the people turn and praise them,

And find no fault in them.

The group of clearly defined sensing types were attracted by the experience and impact of praise and told a number of stories about being praised. They spoke about their curacies and how good people were at offering encouragement and praise. In the move, however, to incumbencies, they spoke about the cruelty of some members of the congregations and the lack of praise offered by them. One person in the group spoke of her experience in relation to a parishioner who said, 'this is your job, this is what you do, so don't expect praise'.

As they had exhausted their detailed analysis of the text of Psalm 73, the group of clearly defined sensing types began to ask some bigger questions around the theological understanding of why good people suffer and why the arrogant get good lives and prosper. To illustrate this point, one participant spoke of the work of Television Evangelists. He highlighted the fact that these people were speaking the good news of Jesus Christ, but that they were also lining their own pockets in the process. 'They were using God for their own benefit', was the phrased used. The group felt challenged by the Psalm and spoke about the unfairness, contrasting the experiences of those who do good and those who look after themselves. In order to respond to the challenge, one member of the group felt that Psalm 73 could be interpreted as exploring the consequences of God offering free will to humanity. How we use our free will affect how we are judged.

The group finished within the time allocation and appointed someone to feedback by coercion rather than by volunteering. 


\section{Intuitive types}

The group of four clearly defined intuitive types followed the instructions. One member of the group read the passage and a period of silent reflection followed. The silence was broken by one member of the group who was clearly perplexed by the exercise. 'Does anyone understand the first question?' he asked, 'What do you see in this description?'.

The question drew an instantaneous response, 'I see myself in this description', came the reply. 'Sometimes I see myself in the first section; I am there with the upright. Sometimes I see myself in the second section; I am there with the wicked'. This pithy response captured the contrasts of the Psalm so succinctly. 'I can be in different places at different times. This is my life'.

Another member of the group read the question in a different way:

'I love the use of language in this Psalm. The language is beautiful. The description is evocative; it is very effective. I can see the fat eyes. I can see them wearing pride like a necklace.'

A third member of the group reflected further on the power of the language:

'There is real physicality in the language. Listen to the power of alliteration: my feet had almost stumbled, my steps had nearly slipped. Or listen to the reference to the pure heart, the heart is a physical centre.'

Impatient with this approach, a different vein of ideas was opened up:

'The other thing that strikes me about this Psalm is how it brings people to mind. It brings to mind the person who is anxious about his own goodness, who is anxious that his feet have nearly slipped. It brings to mind the guy who does not know whether he is upright. There is an awful tension here. He is partly holding on to his wholesome conviction that God is good to the upright, and partly slipping and being envious of the wicked. The wicked are clearly prospering and basking in the praise of the people. Between these two views he is wracked by guilt.'

Another member of the group took this idea in a different direction:

'I see someone whose theological convictions that God is good to the upright have been shot right through. He looks around and it is just not like that. It is the wicked who prosper. They suffer no pain and they enjoy the praise and emulation of the people around them.'

The conversation was then moved in a different direction:

'I am thinking about what I could preach on this Psalm. This Psalm gets to the heart of the pastoral task in which I am engaged. This is about real situations in the world, about real people in my congregation. I can see them sitting there wearing pride like necklace, wearing pride like a fine hat, wearing pride like a finely cut suit. I can see how violence covers them like a garment.'
One member of the group was growing increasingly uncomfortable with the condemnatory reading of the text:

'I just see the author of the Psalm as bitter and twisted. I am asking why would I ever want to read this Psalm, unless I was interested in Hebrew poetry? I would never search it out to read it.'

Another member of the group, however, proposed a more positive reading of the Psalm:

'For me, the idea set running in my mind is the comparison between the wicked and the people who praise them. Who is being ticked off more by the author, the wicked or the people who are stupid enough to praise them? This reflects the incredulity of Christians today about the world in which they are living. We can see what is going wrong in our world, and we wonder why others cannot see it as well. Just think about how people in the USA have been praising President Trump.'

Just as religion was about to collide with politics, the session was brought to an abrupt end by recognition that time had run out. Yet before the group left the room one member observed that most of the time had been spent on the second question, with very little attention given to the first. 'We have been bouncing around some very big themes'.

\section{Results: Psalm 73:15-20, 27-28}

\section{Feeling types}

The group of six clearly defined feeling types began by reading the piece of scripture out loud. They then nominated a member of the group to feedback.

The instant response to Psalm 73 from the group of clearly defined feeling types was one of incredulity and exasperation as they all failed to 'get into the Psalm'. After the initial feeling of frustration, the group looked at the question, 'What issues touch your heart?' The group felt that the writer of the Psalm had written from the bottom of the heart and that the psalm was full of emotion.

One member of the group felt that Psalm 73 was a Psalm of transition. That transition is experienced through waiting and watching with God until there is a shift in the heart. The transition occurs in Psalm 73 when the Psalmist steps into the sanctuary, 'that is when things change'. The group then spent some time discussing the transition from feeling outside the love of God to recognising that one is never outside the love of God. The comment was made by one participant that the person in Psalm 73 'was a mess when they were outside the influence of God'.

In trying to make sense of Psalm 73, the group of clearly defined feeling types returned to the first part of the Psalm to explore whether that helped to make sense of it. They were also keen to know what had happened in the other verses of the Psalm. The group complained that they felt bullied by the redactor, in giving them just this part of the Psalm. One member of the group expressed a harshness in the extract and felt irritated that they could not see the 
whole Psalm, suspecting that there must be a more acceptable picture of God in those verses. The group felt the need to put 'a nice gloss' on the Psalm. They may be willing to talk about a God of justice, but never about a God of retribution.

For three of the participants in the group, the God of the Psalm is not a God with whom they have a relationship. They found Psalm 73 depressing. The words are miserable words. If they went to a church that preached this type of God, they were clear that they would move churches. The participants in this group wanted a relationship with a God of love, not with the God that was being portrayed in Psalm 73. Another participant in the group cautioned the rest of the group to remember, 'that it is not God who has written this'.

The group then turned to the second questioned posed, 'What theological issues stretch my mind?' In an immediate response to this question, one member of the group raised the problem as to how God could allow those who are hungry and homeless to be hungry and homeless. There was no direct answer given to the question as the group moved quickly on to the whole concept of negativity and truth.

It was clear that the group did not want to worship a harsh God, but a God of love. As they reflected on this notion of a harsh God, they moved on to talk about truth and where truth claims lay. They tackled the theological statement read at the end of some Bible passages, 'this is the Word of the Lord'. How do you determine what is the Word of the Lord and what is not the Word of the Lord? How does a person understand, 'what is the true Word of God'. The group was ill at ease in accepting the portion of Psalm 73 as they were working on the 'Word of God' because of its negativity. They felt that such negativity would influence worship and people would leave the worship with negative thoughts rather than positive feelings.

In summary, the group struggled 'to get their head' around Psalm 73 and expressed concerns about the mental health of the Psalmist. One participant felt that the writer was a 'disturbed person'. Another participant detested Psalm 73 so much that 'they could not get into it'. What gave the group hope was the verse in the Psalm that said, 'it is good to be near God; I have made the Lord God my refuge, to tell of all your works'. The group argued a number of times during the process and expressed some clearly held strong views against a judgemental God. The whole group was clearly disturbed by Psalm 73 and wanted to hold to the view that their God was a loving God.

\section{Thinking types}

The group of four clearly defined thinking types followed the instructions. One member of the group read the passage aloud and a period of silent reflection followed. The silence was broken by one member of the group who was keen to begin the process of analysis. 'Both questions ask about issues. The first step is to identify the issues and then to see whether they touch the heart or stretch the mind'. Here a logical strategy was offered to follow.

The first concept to catch the interest of this group was the concept of truth. 'I have been untrue to the circle of your children. The issue is untrue to what?' Another member of the group wanted to start somewhere else:

'The issue for me is that I do not like the writer of this Psalm. I have no sympathy for him. That leaves me with a distinct distance from the writer. Here is someone who thinks he is speaking for God. He sees the wicked flourish in the world. His trust in God's fairness and justice has been shattered when he sees the wicked flourish. Then he goes into the sanctuary, comes face-to-face with God and the problem is solved. Now he sees the wicked destroyed in a moment. They fall to ruin. In one sense, he is trying to say something about God's justice, but I feel uncomfortable with that view of God. It is not right for someone so close to God to wish such destruction on others. That is not justice. That is not fairness.'

A second voice picked up this theme:

'I am worried by the theology of the writer. Here is someone dealing with the problem of evil in the world and trying to overcome evil with evil. There is something fundamentally flawed with the theology that God rewards the upright and brings plagues and destruction on the wicked. This is the theology that Job confronted when his comforters urged him to repent of the sin that has brought about his downfall. Job maintained his righteousness and cried aloud to God to explain his grief.'

The analysis continued:

'Here is a profound sense of betrayal. The writer is tired of looking on at the prosperity of the wicked and he fears that the evidence that he sees all around him is now drawing him away from the path of righteousness. But his solution is no real solution. He draws close to God, ignores all the evidence and repeats his conviction. He will go on telling people that God is good to the upright.'

The analysis continued further:

'The issue is about how we deal with those of whom we disapprove - or more to the point with those of whom we suspect God disapproves. Do we take the view that they will go to hell in a handcart, and that we will survive? Do we hope for their destruction, or do we pray for their transformation?'

\section{Another voice chipped in:}

'The overall thing is about the religious culture that makes people so self-righteous; that makes people feel that they know God better than others know God. They make God their refuge and act as if they know the mind of God.'

A further voice chipped in:

'What stretches my mind is to see the discrepancy between how the Psalmist saw things, and how Jesus saw things. Jesus said that he came not to call the righteous but to call sinners to repentance. Jesus did not come to destroy sinners but to offer them new life.' 
For this group of four thinking types, the time had passed quickly and there were still things to say when time had run out. The group concluded by reflecting that they had been working hard on analysing a core problem in Christian theology: why do good people not prosper more; and do bad people not get their comeuppance more often? They had been energised by analysing the problem, but not left unaffected by the agonising and discomfort that the Psalmist's approach to this problem had generated.

\section{Discussion}

In keeping with the SIFT approach to biblical hermeneutics, the present study was designed to explore the different responses to Psalm 73 that might be associated with preferences for the four psychological functions first differentiated by Carl Jung (1971) in Psychological Types. Verses 1-10 of Psalm 73 were selected to be discussed by groups differentiated by the perceiving function that members preferred to process information, the sensing function or the intuitive function. These verses were rich in content that might engage the perceiving process. Verses 15-20 and 27-28 of Psalm 73 in turn were selected to be discussed by groups differentiated by the judging function that members preferred to evaluate information, the feeling function or the thinking function. These sets of verses were rich in content that might engage the judging process.

In the foregoing presentation of results, distinctive voices seem to arise from the deployment of each of these four functions (sensing, intuition, feeling and thinking). The purpose of this section is to discuss these findings in relation to wider issues in psychological type theory and in dialogue with the emerging body of research from an empirical inquiry into the SIFT approach to other biblical narratives, including similar studies of other Psalms.

\section{The sensing function}

Jung understood sensing as the function that 'mediates the perception of the physical stimulus' (Jung 1971:461) and 'tells me something exists' (Jung 1977:12). For Detloff (1972:67), sensing 'is especially useful in relating to immediate reality'. Moreover, according to type theorist Scott Anchors (1989:12), 'well developed sensation is a comprehensive impression of life ... filtered through the five senses' so that at the psychological level, 'clarity and simplicity are its key contributions to consciousness' (Ross \& Francis 2020:16).

The sensing function's focus on clarity emerged early in the group of sensing types. The group members argued at first, wishing to be certain that they clearly understood the task, and then fell silent to read the scripture portion until one member asked how precisely were they to go about discussing the verses. The sensing types were engaged by the Psalmist's offended sense of justice, resonating in a straightforward way to the lack of what has been termed 'natural justice' (Goodheart 1953). They observed the discrepancy between bad behaviour and its consequences: one member remarked on how 'the arrogant get way with their arrogance', whilst another member emphasised that these arrogant individuals were actually rewarded by the praise of others. A third member resonated to the manifest unfairness. Overall the sensing types seemed sympathetic to the Psalmist's envy because the injustice was so clearly palpable. Furthermore, they were persuaded by the graphic depiction of the Psalmist: 'they have no pain; their bodies are sleek and sound; pride is their necklace; violence covers them like a garment'. The Psalmist is using the language of the senses and the sensing types seem won over. The complexities, however, of the emotion of envy were neither engaged nor discussed.

The Psalmist's clear descriptions replete with striking visual images triggered strong memories in the sensing types of themselves being praised and these strong memories were then recounted. This triggering by present stimuli of comparable earlier experiences, which are then experienced in an eidetic manner, that is, actually re-experienced together with visceral emotional sensations, is an occurrence that has been reported as a defining characteristic of the sensing function operating with an introverted orientation (Myers 1980). The sensing function, because it preserves in consciousness the physical stimuli for the five senses, effortlessly and naturally orients to specifics. Francis et al. (2019), for instance, describe introverted sensing as orienting:

To the present by looking out for what is familiar and selecting that part of the present because it has been strongly experienced before and [furthermore] is therefore safe and comfortable. (p. 5)

Sensing types tend to be concerned with immediate reality and this was evidenced in this group of sensing types by members referring to experiences in their curacies where 'good' parishioners praised their work and 'cruel' ones did not.

It is likely that most of the five sensing types were using introverted sensing because introverted sensing - along with extraverted feeling - are the most frequent specific function-orientations amongst those attracted to organised religion in general, and amongst most Catholic and Protestant Christian congregations in particular. In contrast, extraverted sensing - along with the introverted thinking are the rarest function-orientations in most religious groups (Francis, Robbins \& Craig 2011; Ross 2011).

The findings of this study are in keeping, therefore, with psychological type theory in that it was only after their careful attention to specific details of the text of Psalm 73 that the sensing types negotiated the more general theological conundrum of good people suffering whilst arrogant people prosper. By the same token, indicative of the sensing types' resonance to specifics and introverted sensing attention to detail, one member immediately went to a current example of television evangelists being financially enriched by viewers' donations: 'Using God for their own benefit'. The session ended with members returning to the stark contrast between the conditions of the good and those of the selfish. 


\section{The intuitive function}

According to Jung (1971:453), intuition is 'the function that mediates perceptions in an unconscious way' enabling us to see the 'unseen' (Ross 1992:84). Moreover, there is an involuntary aspect to intuition: 'you do not make an intuition. On the contrary it comes to you' (Jung 1970:41). This involuntary and unconscious - beneath the surface of awareness - aspect of the intuitive function's operation may account for the shear variety of contrasting features that characterise each intuitive type's individualised response to the same text. Furthermore, 'intuition connects us to possibilities' (Ross \& Francis 2020:16). The manner in which the members of the intuitive group started their discussion of Psalm 73 was in keeping with these descriptions of the operations of the intuitive function: the intuitive types immediately engaged with the text in a personalised manner and felt no compunction about making a markedly different interpretation compared with the preceding member's remarks. There was an acceptance of what may be described as the automatic personalising of intuitive types' reactions. Each intuitive participant was at peace with the creative variety that was elicited by features of the text.

Sensing types and intuitive types have been reported as using and experiencing language in different ways (Ross 1992). Findings from the present study offer confirmation of the way that language, both in its spoken and written aspects, works differently for sensing types and for intuitive types. For sensing types, language works in a denoting way pointing to 'reality', whereas for intuitive types, language works in a connotative manner - setting-off lateral associations - in which elements of awareness cluster based on meaningful patterns formed through language. By contrast, in the operations of the sensing function, the physical aspects of stimuli or object have primacy in that function's relationship to language.

Whereas for the sensing types, the textual images triggered eidetic and visceral response associated with past memories of specific experiences, for the intuitive types, a variety of meanings were articulated, along with a communicated comfort with complexity, not only within the situation depicted in the text but also applied within individuals, including not just the inner workings of the Psalmist but those of group members. One group member, for example, declared 'Sometimes I see myself in the first section; I am there with the upright. Sometimes I see myself in second; I am there with the wicked'. Sensing types had also observed and remarked upon the contrasts depicted in Psalm 73. However, there was readiness in the intuitive group to personalise the contrasts and acknowledge and accept the same within their own self and their own life.

Intuitive types' comfort with complexity may help explain the finding in an early study of the religious differences between sensing and intuitive types in which sensing types were found to be more troubled by religious doubt compared with intuitive types, for whom religious doubt was deemed as just another instance of complexity (Ross, Weiss \& Jackson 1996). Simply put, intuitive types are accustomed to construing the world in complicated ways. This is reflected in the correlation that has been noted between the sensing-intuitive preference, a component of the Myers Briggs Type Indicator and openness to experience, a factor of the Five-Factor Model of Personality (McCrae \& Costa 1989). In keeping with this established and documented aspect of intuition, the participants in the intuitive group seem to assume that there is an unargued legitimacy to their imaginings, not necessarily that they are true in themselves but that their musings are worth sharing because they may help fill out and contribute to a more comprehensive truth. Contrasting workings with language by sensing types and intuitive types may correspond in philosophy and philosophical theology in regard to contrasting but complementary theories of truth. Whilst the intuitive function orients to the coherence theory of truth, where evidence from different directions or fields is adduced to the growing validity of a theory or proposition, the sensing function orients to the correspondence theory of truth where a statement, proposition or theory is true if it denotes or is isomorphic - having the same shape as with the way things are.

If this had not been a type-alike group where all members shared intuition as their preferred mode of perceiving, it is likely that sensing types would have challenged the assumptions that intuitive types seemed to presume as true, and these intuitive explorations of Psalm 73 may have been inhibited. By the same token, in a type-mixed group, the sensing types may have been deterred from the articulation of their careful text-based comments and the freshness of the discussion in the sensing group of this study may have been lost.

\section{The feeling function}

Jung saw feeling as a rational function on a par with thinking, in that it organises our perceptions. By doing so, Jung rehabilitated feeling to an equal place alongside thinking, following the demotion of the feeling function in the 19th century with the rise of technology and the industrial revolution. Organised religion is unique amongst the institutions of Western societies in being an institution in which feeling takes precedence over thinking as reflected in the large preponderance of feeling types over thinking types in religious groups (Francis et al. 2011; Ross 2011). For Jung, feeling is a general ordering function based on human valuing, which extends beyond contents that have an obvious emotional component (Ross \& Francis 2020:28).

Jung claimed that feeling is a function that imparts 'a definite value to the content of consciousness' (McGuire \& Hull 1977:435). For Myers (1980), feeling orders perception. When well-developed, Myers claimed that the feeling function becomes a stable instrument for discriminating the worth of personal values and serves as the bridge between one human being and another. However, whereas thinking needs some 
distance from what it perceives in order to operate, feeling requires involvement in order to 'get a feel' for the objects of consciousness and decide upon them (Ross \& Francis 2020:28). These descriptions of the feeling function and its operations in consciousness were exemplified in the discussion engaged by those in the group of feeling types.

The 'close up' operating mode of the feeling function was apparent from the outset of the group discussion, with immediate expression of their own strong feelings to the overall retributive tone of the Psalmist. The feeling function works by moving into a ready identification with another person's utterance as recorded in written material, but the retributive content thwarted ready identification. However, such is the vigilance of the feeling function for these opportunities for identification that members of the feeling group converged on a shared empathy for the Psalmist as 'writing from the bottom of his heart'. This reflected the feeling types' eagerness to sympathise if at all possible. Thus, they contextualised their own initial frustration by noting the Psalm was full of emotion, and by way of compensation that allowed them to transition from their initial challenging frustrated reaction. In fact, the discussion was characterised by the number of sharp transitions as one feeling gave way to another. Furthermore, several of the group members focused on the abrupt transitions the Psalmist himself evidenced, for instance: 'the person in Psalm 73 "was a mess when they [sic] were outside the influence of God"'.

Given the findings of numerous type studies showing the high frequency of extraverted feeling types in Christian groups, it is likely that for several of the group members extraverted feeling was more consciously differentiated than introverted feeling; extraverted feeling orients to external harmony between people or threats to such harmony (Ross \& Francis 2020). It is in keeping with psychological type theory that several in this group thought felt bullied by the text redactor - and felt it appropriate to report the same - who in the design of the study selected only parts of the text for interpretation and comment. Some members were so uncomfortable with the 'harshness in the extract' that they expressed a wish that a more acceptable view of God must be in those other verses that the redactor had left out. By the same token, the group observer noted that 'the group felt the need to put a "nice gloss" on the Psalm'.

Members of the group of feeling types were open and direct about their feelings, ranging from not being able or willing to disguise their initial recoil at the start to expressing strong opinions towards the end of the discussion of their responses. For example, the Psalm in question was 'depressing' and its words 'miserable'. The feeling types were likewise concerned about the impact on their church members if they 'preached this type of God' and expressed fear that church members would leave for another church.

Overall, whilst there was an attempt to be empathic to the situation of the Psalmist, the group observer seemed to register that there was something fundamentally abhorrent to members of the group of feeling types concerning a divine being depicted as punitively judgemental, so much so that the issue was returned to, and hotly contested, numerous times during the $30 \mathrm{~min}$ discussion period. This underscores the basic way in which the feeling function operates - by moving towards and engaging sympathetically with the objects of perception and sorting them according to their impact on human valuing - something that is vitiated when this is not possible, and therefore very frustrating to feeling types.

\section{The thinking function}

According to Jung (1971:481), 'Thinking is the psychological function which ... brings the contents of its ideation into conceptual connection with one another'. Thinking is a way of deciding that 'employs logical analysis based on cause effect analysis' (Hunziker 2016:132). In keeping with these definitions, the group of thinking types tried to come to terms with their dissonance in relation to the Psalmist's vengeful and divisive commentary, by trying to articulate the ideas that might be in play for the Psalmist, albeit not necessarily in his awareness. Articulating such ideas that might go some way in explaining the theme of retribution that characterised both the Psalmist's own response and the attributions he made to the God to whom he related. The second speaker in the group referred overtly to theology. The Psalmist's dichotomising theology was contrasted to the more complex theology conveyed by Job's grief-filled outcry to God when Job is depicted in a similar situation. This same speaker then musters a robust rejoinder that sustains an argument through a number of related analyses: the concept of betrayal is invoked and fear of his own loss of faith hypothesised as the reason for a possibly violent fantasy of what should happen to the wicked. Having prepared the intellectual ground in this way, the speaker then plausibly situates the Psalm in a wider ethical context, that of how we deal with those we disapprove or more to the point [adding tellingly] with those of whom we suspect God disapproves'. Here, we see the thinking function operating: it is doing its analytic work, trying to infuse some logic into the Psalmist's exclamations in order to make them, if not acceptable as a moral answer, at least comprehensible as a moral dilemma, by means of articulating a wider, if still questionable, system of thought. The thinking function is less 'upset' by struggle and conflict compared with the way that the feeling function is affected; rather the thinking function is mobilised and challenged to find some consistency in the phenomena in which the individual is immersed so that others may be engaged with the Psalmist's situation in some way.

The thinking function carries within its operations a drive to understand what may seem at first to be incomprehensible. For the thinking function to operate, however, the felt intensity must be muted in some way and this is achieved through conceiving ideas that will achieve a critical distance by means of analysis. As Myers (1980:65) says of thinking, 
'Thinking is essentially impersonal. Its goal is objective truth, independent of the personality and wishes of the thinker or anyone else'.

The robustness of the second speaker's rejoinder during the early interaction within the group of thinking types lies in the invocation of the concept 'betrayal', a term that engenders high emotion. However, the speaker employs it analytically so that interest is engaged, at least for this group of thinking types. The remark serves to clarify baldly the moral issue so often at stake in the wake of strong disapproval: 'Do we hope for their destruction, or do we pray for their transformation?' Once the issue has been so tersely formulated, the group is freed to progress to the concluding queries in quick succession: 'What makes "people of God" so prone to be selfrighteous?' and then finally the discrepancy is confronted between this Psalmist's dichotomising outlook and Jesus' call to repentance and his offer of new life.

In conclusion, the thinking function is more concerned to pose questions clearly than it is to find answers: even without answers, the note-taker registered that the group ended on an energetic note, having 'worked the problem'. For thinking types, moral discomfort, even when it evokes indignation, is not dysphoric in the way that it is for feeling types because of the latters' preference for harmony. On the contrary, the challenge to make sense of 'the difficult' may be energising when relevant categories and distinctions become available courtesy of the thinking function. Such relishing of adversity and the stamina it engenders may be hard for feeling types to comprehend and is another argument for the importance of type literacy in effecting and sustaining religious and spiritual communities.

\section{Conclusion}

The research programme designed to explore and test the SIFT approach to biblical hermeneutics was initiated by a study of the Marcan account of the feeding of the 5000 (Francis 2010). The first phase of this research programme continued by focusing on passages from the four Gospels. The second phase of this research programme turned attention to the very different kind of biblical literature found in the Psalms. The second phase was initiated by studies on Psalm 1 (Francis et al. 2018; Francis \& Smith 2018) and on Psalm 139 (Francis, Smith \& Corio 2018). The aim of the present study was to extend the second phase of the research programme by focusing on Psalm 73 and to do so amongst an international group of theological educators working within an Anglican context in Cyprus. Psalm 73 was found to be rich in material to engage the perceiving process, distinguishing between sensing and intuition, and also to be rich in material to engage the judging process, distinguishing between thinking and feeling.

The findings from the present study provide additional richness to the cumulative body of evidence confirming just how much the psychological type preferences of the reader shape the interpretation of biblical materials. Such findings suggest that the reader-perspective approach to biblical hermeneutics, originally shaped within an environment informed by sociological theory, may be incomplete without sociological perspectives being properly complemented by psychological perspectives.

Future research in this tradition may now wish to draw on other Psalms to complement and to enrich, or to contradict and to challenge, the conclusions currently emerging from work on Psalms 1, 73 and 139.

\section{Acknowledgements Competing interests}

The authors have declared that no competing interests exist.

\section{Authors' contributions}

L.J.F. conceptualised the article. L.J.F. and S.H.J. served as observers in the groups. C.F.R. organised the discussion. All three authors analysed the data.

\section{Ethical consideration}

This article followed all ethical standards for a research without direct contact with human or animal subjects.

\section{Funding information}

This research received no specific grant from any funding agency in the public, commercial or not-for-profit sectors.

\section{Data availability statement}

Data sharing is not applicable to this article as no new data were created or analysed in this study.

\section{Disclaimer}

The views and opinions expressed in this article are those of the authors and do not necessarily reflect the official policy or position of any affiliated agency of the authors.

\section{References}

Anchors, S., 1989, 'Type development and different types', Bulletin of Psychological Type 21, 10-12.

Detloff, W., 1972, 'Psychological types: Fifty years after', Psychological Perspectives 3(1), 62-73. https://doi.org/10.1080/00332927208408804

Francis, L.J., 2005, Faith and psychology: Personality, religion and the individual, Darton Longman and Todd, London.

Francis, L.J., 2010, 'Five loaves and two fishes: An empirical study in psychological type and biblical hermeneutics among Anglican preachers', HTS Theological Studies 66(1), article 811, 1-5. https://doi.org/10.4102/hts.v66i1.811

Francis, L.J., 2012a, 'What happened to the fig tree? An empirical study in psychological type and biblical hermeneutics', Mental Health, Religion and Culture 15(9), 873891. https://doi.org/10.1080/13674676.2012.676252

Francis, L.J., 2012b, 'Interpreting and responding to the Johannine feeding narrative: An empirical study in the SIFT hermeneutical method among Anglican ministry training candidates', HTS Theological Studies 68(1), article 1205, 1-9. https://doi. org/10.4102/hts.v68i1.1205

Francis, L.J., 2013, 'Ordinary readers and reader perspective on sacred texts: Drawing on empirical theology and Jungian psychology', in J. Astley \& L.J.Francis (eds.), Exploring ordinary theology: Dimensions of everyday Christian existence and the life of the Church (pp. 87-96), Ashgate, Farnham, England. 
Francis, L.J., 2015, 'Footwashing and diaconal ordination', in J. Vincent (ed.), The farewell discourses in practice (pp. 21-28), Deo Publishing, Blandford Forum, England. https://doi.org/10.1163/9789004397316_006

Francis, L.J. \& ap Siôn, T., 2016a, 'Jesus, psychological type and conflict: A study in biblical hermeneutics applying the reader perspective and SIFT approach to Mark 11:11-21', HTS Theological Studies 72(4), 1-9. https://doi.org/10.4102/hts. v72i4.3573

Francis, L.J. \& ap Siôn, T., 2016b, 'Empirical theology and biblical hermeneutics: Exploring lessons for discipleship from the Road to Emmaus (Luke 24:13-35)', Journal of Empirical Theology 29(1), 24-44. https://doi.org/10.1163/1570925612341000

Francis, L.J. \& ap Siôn, T., 2017, 'Reading the Lucan call of the first disciples differently: The voices of sensing and intuition' Journal of Beliefs and Values 38(2), 188-198. https://doi.org/10.1080/13617672.2017.1291254

Francis, L.J. \& Jones, S.H., 2011, 'Reading and proclaiming the resurrection: An empirical study in psychological type theory among trainee and experience preachers employing Mark 16 and Matthew 28', Journal of Empirical Theolog 24(1), 1-18. https://doi.org/10.1163/157092511X571141

Francis, L.J. \& Jones, S.H., 2014, 'Life in the Eucharistic community: An empirical study in psychological type theory and biblical hermeneutics reading John 6:5-15', Pastoral Psychology 63(3), 281-290. https://doi.org/10.1007/s11089-013-0540-x

Francis, L.J. \& Jones, S.H., 2015a, 'An empirical approach to Mark's account of discipleship: Conversation between the Word of God and the People of God', Rural Theology 13(1), 69-81. https://doi.org/10.1179/1470499415Z.00000000042

Francis, L.J. \& Jones, S.H., 2015b, 'Preparing for Disability Awareness Sunday: An educational exercise drawing on psychological perspectives for biblical hermeneutics', International Journal of Christianity and Education 19(3), 197-214. https://doi.org/10.1177/2056997115602485

Francis, L.J., Jones, S.H. \& Hebden, K., 2019, 'Binding and loosing on earth: Evaluating the strategy for church disciplinary procedures proposed in Matthew 18:15-18 through the lenses of thinking and feeling, HTS Theological Studies 75(3), articl 5474, 1-10. https://doi.org/10.4102/hts.v75i3.5476

Francis, L.J., Jones, S.H. \& Martinson, J., 2019, 'Exploring the Marcan account of the Baptism of Jesus through psychological lenses: An empirical study within a Blackled Black-majority Pentecostal church', Journal of the European Pentecostal Theology Association 39(2), 100-115. https://doi.org/10.1080/18124461.2019.1 Theology
592330

Francis, L.J., McKenna, U. \& Sahin, A., 2018, 'Facing the issues raised in Psalm 1 through thinking and feeling: Applying the SIFT approach to biblical hermeneutics among Muslim educators', Religions 9(323), 1-11. https://doi.org/10.3390/ rel9100323

Francis, L.J., Robbins, M. \& Craig, C.L., 2011, 'The psychological type profile of Anglican churchgoers in England: Compatible or incompatible with their clergy?', International Journal of Practical Theology 15(2), 243-259. https://doi. org/10.1515/IJPT.2011.036

Francis, L.J. \& Ross, C.F., 2018, 'Psychologically-informed engagement with the Matthean pericopes on Pilate and Judas through Jungian lenses: The SIF approach', HTS Theological Studies 74(1), 1-12. article 5179. https://doi. org/10.4102/hts.v74i1.5179

Francis, L.J. \& Smith, G., 2012, 'Separating sheep from goats: Using psychological type theory in a preaching workshop on Matthew 25:31-46', Journal of Adult Theologica Education 9(2), 175-191. https://doi.org/10.1179/ate.9.2.gw21522035374468

Francis, L.J. \& Smith, G., 2013, 'Reading and proclaiming the Birth Narratives from Luke and Matthew: A study in empirical theology among curates and their training incumbents employing the SIFT method', HTS Theological Studies 69(1), article incumbents employing the SIFT method', HTS Theolog
2001, 1-13. https://doi.org/10.4102/hts.v69i1.2001

Francis, L.J. \& Smith, G., 2014, 'Reading and proclaiming the Advent call of John the Baptist: An empirical enquiry employing the SIFT method', HTS Theological Studies 70(1), article 2718, 1-9. https://doi.org/10.4102/hts.v70i1.2718
Francis, L.J. \& Smith, G., 2017, 'Learning relationships: Church of England curates and training incumbents applying the SIFT approach to the Road to Emmaus', HTS Theological Studies 73(4), 1-11. article 4546. https://doi.org/10.4102/hts.v73i4.4546

Francis, L.J. \& Smith, G., 2018, 'Difficult texts: Psalm 1', Theology 121(3), 197-200. https://doi.org/10.1177/0040571X17749149

Francis, L.J., Smith, G. \& Corio, A.S., 2018, 'I hate them with perfect hatred: Exploring Psalm 139 through the Jungian lenses of sensing, intuition, feeling, and thinking', HTS Theological Studies 74(1), 1-9. article 5058. https://doi.org/10.4102/hts.v74i1.5058

Francis, L.J., Smith, G. \& Francis-Dehqani, G., 2017, 'The missionary journey of Mark 6 and the experience of ministry in today's world: An empirical study in biblical hermeneutics among Anglican clergy', HTS Theological Studies 73(3), 1-7. article 4560. https://doi.org/10.4102/hts.v73i3.4560

Francis, L.J., Strathie, D. \& Ross, C.F., 2019, 'Reading the Beatitudes (Matthew 5:1-10) through the lenses of introverted intuition and introverted sensing: Perceiving text differently', HTS Theological Studies 75(4), article 5475, 1-8. https://doi. org/10.4102/hts.v75i4.5475

Francis, L.J. \& Village, A., 2008, Preaching with all our souls, Continuum, London.

Goodheart, A.L., 1953, English law and the moral law, Stevens, London.

Hunziker, M., 2016, Depth typology, C. G. Jung, Isabel Myers, John Beebe and the guide map to becoming who we are, Write Way Publishing Company, Clayton, NC.

Jones, S.J. \& Francis, L.J., 2019, 'Searching for the lost sheep (Matthew 18:10-14): Do sensing types and intuitive types find different things?', Rural Theology 17(2), 106-113. https://doi.org/10.1080/14704994.2019.1585112

Jung, C.G., 1970, Psychology and religion, West and East: Collected works of C.G. Jung, vol. 11, Princeton University Press, Princeton, NJ.

Jung, C.G., 1971, Psychological types: The collected works, vol. 6, Routledge and Kegan Paul, London.

Jung, C.G., 1977, The symbolic life: Collected works of C.G.Jung, vol. 18, Princeton University Press, Princeton, NJ.

Keirsey, D. \& Bates, M., 1978, Please understand me, Prometheus Nemesis, Del Mar, CA.

Kirkpatrick, A.F., 1903, The Book of Psalms, Cambridge University Press, Cambridge.

McCrae, R.R. \& Costa, P., 1989, 'Reinterpreting the Myers-Briggs Type Indicator from the perspective of the five-factor model of personality', Journal of Personality 57(1), 17-40. https://doi.org/10.1111/j.1467-6494.1989.tb00759.x

McGuire, W. \& Hull, R.F.C. (eds.), 1977, C.G. Jung speaking: Interviews and encounters, Princeton University Press, Princeton, NJ.

Myers, I.B., 1980, Gifts differing, Consulting Psychologist Press, Palo Alto, CA.

Myers, I.B. \& McCaulley, M.H., 1985, Manual: A guide to the development and use of the Myers-Briggs Type Indicator, Consulting Psychologists Press, Palo Alto, CA.

Ross, C.F.J., 1992, 'Orientation to religion and the feeling function in Jung's personality Typology', Studies in Religion 21(3), 305-320. https://doi.org/10.1177/ 000842989202100307

Ross, C.F.J., 2011, 'Jungian typology and religion: A perspective from North America', Research in the Social Scientific Study of Religion 22, 166-191. https://doi. org/10.1163/ej.9789004207271.i-360.30

Ross, C.F.J. \& Francis, L.J., 2020, Personality, religion, and leadership: The spiritual dimensions of psychological type theory, Lexington Books, New York, NY.

Ross, C.F.J., Weiss, D. \& Jackson, L., 1996, 'The relation of Jungian psychological type to religious attitudes and practices', The International Journal for the Psychology of Religion 6(4), 263-279. https://doi.org/10.1207/s15327582ijpr0604_3

Smith, G. \& Francis, L.J., 2016, 'Difficult texts: Mark 10:46-52', Theology 119(3), 200-203. https://doi.org/10.1177/0040571x15623706

Weiser, A., 1962, The Psalms: A commentary, SCM Press, London. 